\title{
Mothers Knowledge and Perception of Toddler Growth Monitoring Using iPosyandu Application
}

\author{
Ari Indra Susanti, Fedri Ruluwedrata Rinawan, Indah Amelia \\ Department of Public Health, Faculty of Medicine, Universitas Padjadjaran, Bandung, Indonesia
}

\begin{abstract}
Growth monitoring of toddler in Indonesia is an essential thing that should be done by a mother using the Child Health Card (Kartu Menuju Sehat/KMS). This card purpose is also to detect the growth interference of a toddler. However, the KMS cannot be directly filled by working mother because sometimes it is not her who takes the toddler to integrated service posts (pos pelayanan terpadu/posyandu). The iPosyandu application is an application that makes it easy for mothers at any time and anywhere to monitor their children growth. The iPosyandu application can be downloaded at Play Store for free. This research aims to see the knowledge and perception of the mothers in growth monitoring of the toddlers using iPosyandu. The descriptive study with cross-sectional approach conducted in October 2017 in Pasawahan Kidul village, Purwakarta regency. The subjects were 81 mothers with toddler recruited using purposive sampling technique. Results showed that $56 \%$ of mothers in $20-35$ years old group and $42 \%$ of mothers with $2-3$ children had only moderate knowledge. Thirty-eight percent of mothers 20-35 years old, 25\% with 2-3 children and mostly had junior high school education level agreed that iPosyandu is beneficial. In conclusion, mothers who have sufficient knowledge would agree to use iPosyandu to monitor the growth of toddlers.
\end{abstract}

Key words: Growth of toddlers, iPosyandu application, knowledge, mothers, perception

\section{Pengetahuan dan Persepsi Ibu dalam Memantau Pertumbuhan Balita Menggunakan Aplikasi iPosyandu}

\begin{abstract}
Abstrak
Pemantauan pertumbuhan balita di Indonesia merupakan hal yang penting dilakukan oleh ibu dengan menggunakan Kartu Menuju Sehat (KMS) yang bertujuan mengetahui gangguan pertumbuhan balita secara dini. Akan tetapi, KMS tersebut tidak dapat secara langsung dilihat oleh ibu yang sedang bekerja karena terkadang bukan ibu yang mengantar balita ke posyandu. Oleh karena itu, aplikasi iPosyandu merupakan suatu aplikasi yang memudahkan ibu setiap saat dan di mana pun berada untuk memantau pertumbuhan berat badan balita berdasar atas usia. Aplikasi iPosyandu dapat diunduh pada Play Store secara gratis. Penelitian ini bertujuan mengetahui pengetahuan dan persepsi ibu dalam memantau pertumbuhan balita menggunakan aplikasi iPosyandu. Penelitian ini menggunakan metode deskriptif dengan pendekatan cross-sectional. Penelitian ini dilaksanakan pada bulan Oktober 2017 pada ibu yang memiliki balita di Desa Pasawahan Kidul, Kabupaten Purwakarta. Subjek penelitian adalah 81 ibu dengan balita yang diambil menggunakan teknik purposive sampling. Hasil penelitian menunjukkan bahwa 56\% ibu dalam kelompok 20-35 tahun dan 42\% ibu dengan 2-3 anak hanya memiliki pengetahuan sedang. Tiga puluh delapan persen ibu berusia 20-35 tahun, 25\% dengan 2-3 anak, dan sebagian besar berpendidikan sekolah menengah pertama setuju bahwa iPosyandu bermanfaat. Simpulan, ibu yang memiliki pengetahuan cukup setuju menggunakan iPosyandu untuk memantau pertumbuhan balita.
\end{abstract}

Kata kunci: Aplikasi iPosyandu, ibu, pengetahuan, persepsi, pertumbuhan balita 


\section{Introduction}

Growth monitoring of toddler is an essential thing to do as early detection of growth disorder. ${ }^{1}$ Children aged 12-59 months need to get growth monitoring service at least eight times a year, to analyze children's growth disorders. Growth disorders can affect children's growth, and development. ${ }^{2}$ Ariyani and Solihat $^{3}$ showed that under-five years old children who are underweight experience developmental delays, especially motoric skills and language.

In Indonesia, toddler growth monitoring usually is done routinely every month at integrated service posts (pos pelayanan terpadu/posyandu) that integrated with pusat kesehatan masyarakat (puskesmas) as a primary health service center. The Ministry of Health (Indonesian: Kementerian Kesehatan) regulates at least $80 \%$ of children should be weighed regularly at posyandu to know their weight growth pattern by health workers. ${ }^{4}$

The Basic Health Research (Riset Kesehatan Dasar/Riskesdas) 2013 mentioned that the achievements of toddler weighing in posyandu is $80.30 \%$, which means that it increases compared to 2012, which was $75.1 \%$. In West Java, the proportion of toddler weighing in posyandu is $80.30 \%$. Although the toddler weighing in posyandu in Indonesia and West Java met the Strategic Plan (Rencana Strategis/Renstra) 2013 target of $80 \%$, it still needs to increase further. ${ }^{5}$

A mother has the first and foremost role in the toddler's growth and development. Mother and family contribute to toddlers growth process by providing balanced nutrition according to their age. The growth monitoring and developmental screening needed periodically in posyandu. The result of toddlers growth monitoring and developmental screening in posyandu recorded in the form of toddler growth chart named the Child Health Card (Kartu Menuju Sehat/KMS) in the maternal and child health (MCH) handbook. ${ }^{6}$ The data recorded manually by a community health worker or midwife who served in posyandu. Manual recording and data processing has several drawbacks; they take time, prone to inaccuracy in input, processing, and reporting. It was also prone to loosing and damaged of $\mathrm{MCH}$ handbook by the mothers. Then, the mother did not want to keep the KMS and decided to give them to keep to cadre because they afraid to lose the KMS.?

To resolve these problems, the researchers developed iPosyandu application as posyandu data processing system and information provider (Figure 1 and Figure 2). The iPosyandu application is mobile apps on the Android operating system that can store data recording of toddlers weighing and height measurement that can be accessed by the mother anytime and anywhere on their own smartphone. ${ }^{8}$

Mobile apps nowadays considered useful and facilitate lots of information access. In a study conducted by Susilawati et al., ${ }^{9}$ mobile application "Sahabat Ibu Balita" can improve mothers knowledge and skill in monitoring toddler growth. In another study by Wahyuni, ${ }^{10}$ mobile application "MOCA" influence in increasing

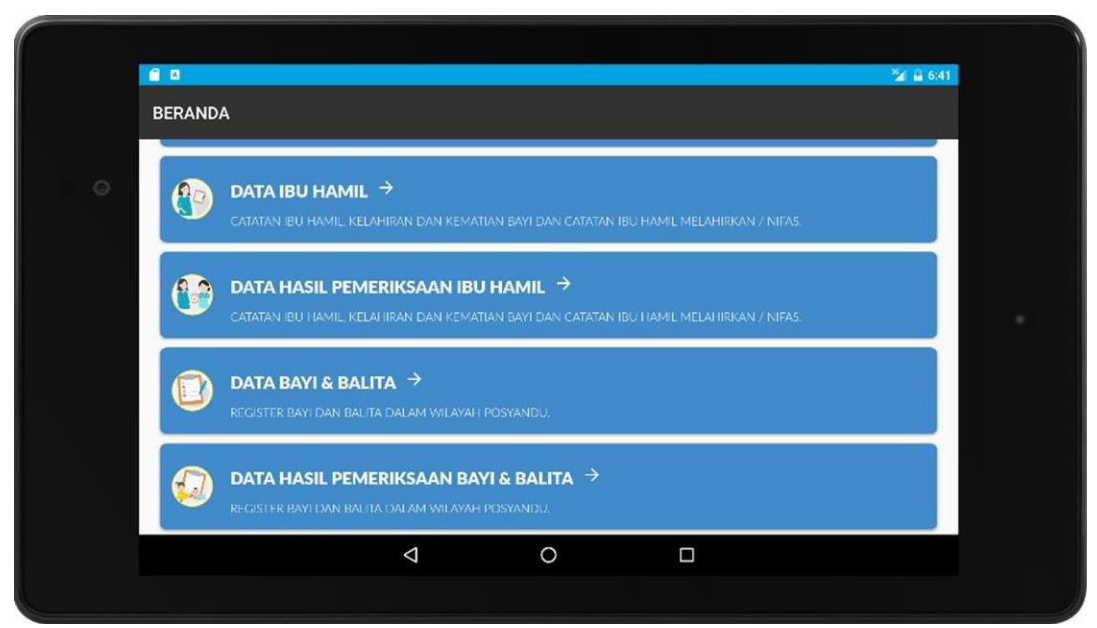

Figure 1 The Application Menu of iPosyandu 


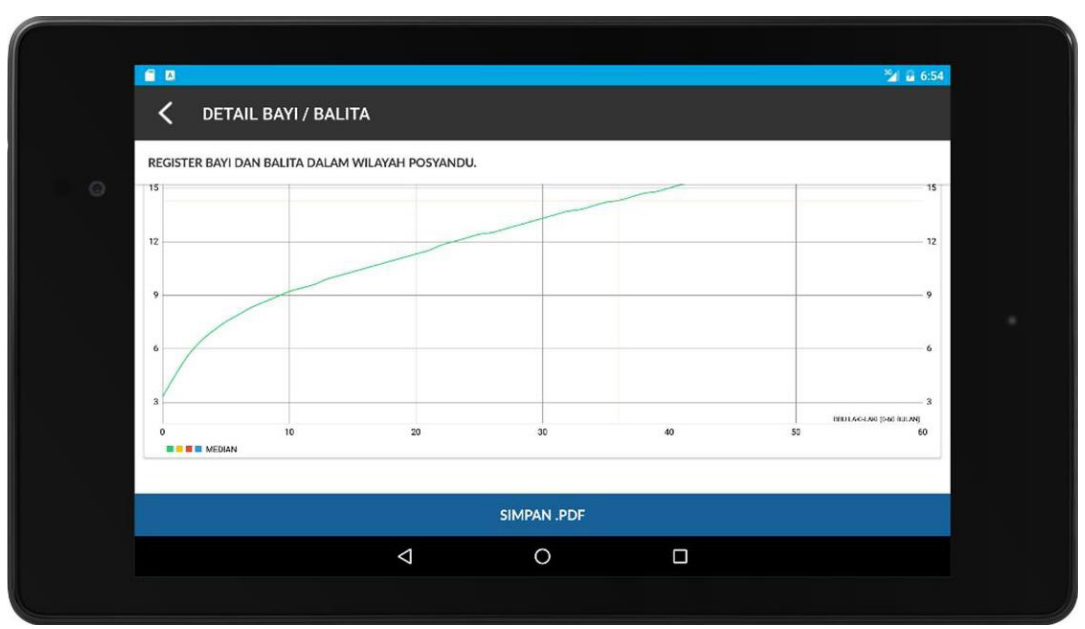

Figure 2 Chart of Toddler Weight Growth

knowledge and skill of parent in stimulating the growth of infants aged 12-18 months.

Based on the background above, the writer interested to find out the mothers knowledge and perception of toddler growth monitoring using iPosyandu application.

\section{Methods}

This research used the descriptive method with a cross-sectional approach. This study conducted in October 2017 to a mother who has a toddler in Pasawahan Kidul village, Purwakarta regency. This research was applied purposive sampling technique, with the total number of the sample was 81 mothers. The data were collected using questionnaires about knowledge of posyandu, $\mathrm{MCH}$ handbook, and toddlers' mother perception about toddlers growth monitoring in posyandu using iPosyandu application. Theinclusion criteria in this study were mothers came to posyandu and agreed to participate. This study approved by the Health Research Ethics Committe, Faculty of Medicine, Universitas Padjadjaran Bandung with letter number: 98/UN6.C10/PN/2017.

\section{Results}

This study is about the mother's knowledge and perception in using iPosyandu application based on age, parity, and education.

Table 1 represents that majority mother who has sufficient knowledge of monitoring toddlers growth using iPosyandu application, is aged
20-35, with 2-3 children and graduated from junior high school. While in Table 2, mothers who agree the most to monitor toddlers growth using iPosyandu application is a mother age 2035 years old.

\section{Discussion}

Based on the results in Table 1, the majority of the mothers with sufficient knowledge is $55.6 \%$ age 20-35 years. The group represents those who frequently access the internet and have more practiced operating internet application. They were the group which familiar with having information and understand the information content from the internet. The age period is also the culmination of physical, cognitive, and socioemotional in human developments. Age affects mindset and comprehension which can be when someone has a mature age, then they increase their knowledge too. ${ }^{11}$

Internet users in Indonesia reach 88.1 million people, and $51 \%$ are women, with $54 \%$ in West Java. ${ }^{12}$ The data shows that women are accessing the internet most often and get much information sourced from the internet.

The internet rated as one of the media most famous as a search tool for the data and health information, one of them as information on mother and child health development. ${ }^{13}$ Currently, information about mother and child development in posyandu is still inferior, difficult to control, and monitored. This problem arises because there is no integrated model data processor and 
Table 1 Mothers' Knowledge Using iPosyandu Application

\begin{tabular}{|c|c|c|c|c|c|c|}
\hline \multirow{3}{*}{ Characteristics } & \multicolumn{6}{|c|}{ Level of Knowledge } \\
\hline & \multicolumn{2}{|c|}{ Good } & \multicolumn{2}{|c|}{ Moderate } & \multicolumn{2}{|c|}{ Not Good } \\
\hline & $n=6$ & $\%$ & $n=55$ & $\%$ & $\mathbf{n}=\mathbf{2 0}$ & $\%$ \\
\hline \multicolumn{7}{|l|}{ Age (years) } \\
\hline$<20$ & $\mathrm{o}$ & o & o & o & o & 0 \\
\hline $20-35$ & 4 & 5 & 45 & 56 & 15 & 18 \\
\hline$>35$ & 2 & 3 & 10 & 12 & 5 & 6 \\
\hline \multicolumn{7}{|l|}{ Parity } \\
\hline 1 & 2 & 3 & 20 & 25 & 5 & 6 \\
\hline $2-3$ & 4 & 5 & 34 & 42 & 12 & 15 \\
\hline$>3$ & o & o & 1 & 1 & 3 & 4 \\
\hline \multicolumn{7}{|l|}{ Education } \\
\hline Uneducated & o & o & o & o & 1 & 1 \\
\hline Not graduated from elementary & o & o & 1 & 1 & o & o \\
\hline Elementary & $\mathrm{o}$ & $\mathrm{o}$ & 8 & 10 & 1 & 1 \\
\hline Junior high & o & o & 22 & 27 & 10 & 12 \\
\hline Senior high & 6 & 7 & 21 & 26 & 7 & 9 \\
\hline College & o & o & 3 & 4 & 1 & 1 \\
\hline
\end{tabular}

information provider that easy to access and read, also fast and accurate. The monitoring system of mother and child health development is very hard in a particular area. Providing decision-making data used on in mothers and child service, were often late, incomplete, and sometimes inaccurate. ${ }^{14}$
The KMS chart of the toddlers' weight and height, which is vital to monitor children growth, not appropriately utilized because the KMS collected in community health worker. The reason, as mentioned before, was because they were afraid to lose it. The comprehension of a mother to the KMS chart is essential that

Table 2 Mothers' Perception Using iPosyandu Application

\begin{tabular}{|c|c|c|c|c|c|c|c|c|}
\hline \multirow{3}{*}{ Characteristics } & \multicolumn{6}{|c|}{ Level of Knowledge } & & \\
\hline & \multicolumn{2}{|c|}{$\begin{array}{c}\text { Strongly } \\
\text { Agree }\end{array}$} & \multicolumn{2}{|c|}{ Agree } & \multicolumn{2}{|c|}{ Disagree } & \multicolumn{2}{|c|}{$\begin{array}{l}\text { Strongly } \\
\text { Disagree }\end{array}$} \\
\hline & $\mathrm{n}=\mathbf{1 2}$ & $\%$ & $n=38$ & $\%$ & $n=26$ & $\%$ & $\mathbf{n}=\mathbf{5}$ & $\%$ \\
\hline \multicolumn{9}{|l|}{ Age (years) } \\
\hline$<20$ & $\mathrm{o}$ & o & 0 & 0 & o & 0 & o & o \\
\hline $20-35$ & 9 & 11 & 31 & 38 & 23 & 28 & 1 & 1 \\
\hline$>35$ & 3 & 4 & 7 & 9 & 3 & 4 & 4 & 5 \\
\hline \multicolumn{9}{|l|}{ Parity } \\
\hline 1 & 4 & 5 & 13 & 16 & 9 & 11 & 1 & 2 \\
\hline $2-3$ & 7 & 9 & 23 & 28 & 16 & 13 & 4 & 5 \\
\hline$>3$ & 1 & 1 & 2 & 3 & 1 & 1 & $\mathrm{o}$ & $\mathrm{o}$ \\
\hline \multicolumn{9}{|l|}{ Education } \\
\hline Uneducated & $\mathrm{o}$ & o & o & o & 1 & 1 & o & o \\
\hline Not graduated from elementary & o & o & 1 & 1 & o & o & o & o \\
\hline Elementary & 3 & 4 & 2 & 3 & 2 & 3 & 2 & 3 \\
\hline Junior high & 2 & 3 & 20 & 25 & 10 & 12 & o & o \\
\hline Senior high & 6 & 7 & 14 & 17 & 11 & 14 & 3 & 4 \\
\hline College & 1 & 1 & 1 & 1 & 2 & 3 & o & o \\
\hline
\end{tabular}


mother can take action as early as possible if the growth of children is not appropriate with their age. The mobile application easily accesses to store toddler's health records, which is why it is important to have it on android-based mobile devices. ${ }^{7}$ To facilitate the mother to get more accessible information about toddlers weight growth and height measurement, iPosyandu application is the answer.

The iPosyandu application is an application that used in posyandu accessed by mothers, community health worker, or health worker. All of the examination of pregnant woman, weighting, height measurement, input in the iPosyandu application by a community health worker or midwife. ${ }^{15}$

Based on the parity, $43 \%$ of mothers with $2-3$ children have sufficient knowledge. Maternal parity can affect the level of knowledge because parity related to mothers experience. The more experience they have, the more knowledge that mother will have. ${ }^{11}$ Mothers tend to seek information over the internet because it is considered easier. Information that sourced from the internet becomes one of the factors that affect the level of someone's knowledge, and the internet becomes a currently essential needs. ${ }^{16}$

Mobile phones nowadays not only used as a communication device but for other needs, such as to do business, access information, play games, and many others. It is so easy to use applications provided on the phone that many internet users are using the phone as a daily necessity. ${ }^{17}$ The increase in technological developments in the era of informatics like this should also be used to stimulate growth and development. This type of information is not difficult to obtain. There is an influence on the use of growth and growth stimulation applications on the level of maternal knowledge and growth of children aged 9-24 months. ${ }^{18}$

According to the WHO in Early Childhood Development and Disability, the community or family environment situation, interaction of children and parents, and access to facilities and infrastructure are some factors that can affect children growth. To achieve the maximum growth and development of children, the role of the family is critical. ${ }^{19}$ The role of parents in the parenting process is vital, especially in meeting the basic needs of children (teaser, foster care, compassion), one of which is the care of nutrition and stimulation. There is a correlation between nutritional and growth and also stimulation with early childhood development. ${ }^{20}$ According to the result of Suryanto et al.'s ${ }^{21}$ research, the role of the family can give positive effect to toddlers growth and development. The mother role in the great of child growth is considered more significant than the father or other family members.

Based on the classification of education, the majority of a mother who graduated from junior high school and high school/vocational school has sufficient knowledge that was 27.9\%. Education can affect mother knowledge. Internet users in Indonesia dominated by users who graduated from high school (64.7\%), bachelor degree (16.9\%), and junior high school (9.7\%). ${ }^{12}$ Education can expand the insight and socialization of people because education can make someone think openly and more efficiently to accept new idea and technologies. The degree of education defined the person to receiving and understanding the knowledge, in general, the higher degree of education then the knowledge will be better. ${ }^{22}$

Based on Table 2, most of the respondents agree to monitor toddlers growth using iPosyandu application. Perception is the process by which people translate sensory impression into a coherent and unified view of the world around them. Though necessarily based on incomplete and unverified (or unreliable) information. ${ }^{19}$ Most of the mother's age 20-35 years agreed to use iPosyandu application to monitor toddlers growth; it was $38 \%$. Age can affect maturity level in thinking and receiving information. Information and knowledge will build someone's mindset and perception. ${ }^{23}$

Moreover, information that mothers get through mobile application can be used easily, affordable, and can be accessed everywhere. It can solve the problem of remote posyandu and the difficulty of transportation to reach posyandu. ${ }^{24}$

Based on parity characteristics, the majority of mothers, $28 \%$ with $2-3$ children agree on iPosyandu to monitoring toddlers growth. Mothers experience of the previous parenting system can develop a mother's ability to build perceptions and decision making that are the result of integrated scientific reason with real problems. ${ }^{25}$

Base on education, 24\% mother who graduated from junior high school, agrees that iPosyandu application using to monitored toddlers growth. The higher education of a person, the more 
comfortable they get information so that the more knowledge they have. However, the knowledge object had both negative and positive aspects. These two aspects can affect perception. Mother knows the more positive aspect, then the possibilities of mother to have positive perception is higher. ${ }^{23}$

\section{Conclusion}

The conclusion of this study is the majority of the mothers that have sufficient knowledge agree to use iPosyandu application to monitor the growth of toddlers.

\section{Conflict of Interest}

All authors have not conflict of interest in publishing this article.

\section{Acknowledgement}

This research funded by Universitas Padjadjaran Internal Grants (HIU) with the Universitas Padjadjaran Lecturer Competency Research (RKDU) Scheme and the Kreasi Insani Persada Foundation.

\section{References}

1. Haymond M, Kappelgaard AM, Czernichow $\mathrm{P}$, Biller BMK, Takano K, Kiess W, et al. Early recognition of growth abnormalities permitting early intervention. Acta Paediatr. 2013;102(8):787-96.

2. Pusat Data dan Informasi, Kementerian Kesehatan Republik Indonesia. Situasi balita pendek. Pusdatin [Internet]. 4 April 2016 [cited 2017 November 15]. Available from: http://www.depkes.go.id/resources/ download/pusdatin/infodatin/situasi-balitapendek-2016.pdf.

3. Ariyani H, Solihat A. Gambaran tumbuh kembang dan status gizi balita bawah garis merah. JKKI. 2014;10(2):981-92.

4. Pusat Promosi Kesehatan, Kementerian Kesehatan Republik Indonesia. Ayo ke posyandu setiap bulan [Internet]. 2012 [cited 2017 November 15] Available from: http:// promkes.kemkes.go.id/download/jrc/ files527obuku_saku_Posyandu.pdf.

5. Badan Penelitian dan Pengembangan Kesehatan, Kementerian Kesehatan Republik
Indonesia. Riset kesehatan dasar (Riskesdas) 2013. Jakarta: Badan Litbang Kesehatan, Kemenkes RI; 2013.

6. Dardjito E, Sistiarani C, Nurhayati S. Deteksi pertumbuhan dan perkembangan balita melalui penggunaan buku KIA. Kesmasindo. 2014;6(3):166-75.

7. Windasari IP, Yana RR. Aplikasi mobile kartu menuju sehat (M-KMS). Jsiskom. 2016;6(2):80-3.

8. Supriyanto A, Hartono B. Peran teknologi informasi bagi kader posyandu dalam kegiatan pendataan KIA. Semnasvoktek. 2017;2:360-5.

9. Susilawati, Rusmil K, Dhamayanti M. Sahabat Ibu Balita: aplikasi untuk meningkatkan pengetahuan dan keterampilan ibu tentang pertumbuhan dan perkembangan anak. JKA. 2017;10(1):74-85.

10. Wahyuni T. Pengaruh aplikasi Mother Cares (MOCA) terhadap peningkatan pengetahuan dan keterampilan orang tua dalam melakukan stimulasi tumbuh kembang balita usia 12-18 bulan. JMC. 2017;4(1):28-36.

11. Thomas S, Kunzmann U. Age differences in wisdom-related knowledge: does the age relevance of the task matter? J Gerontol B Psychol Sci Soc Sci. 2014;69(6):897-905.

12. Asosiasi Penyedia Jasa Internet Indonesia, Pusat Kajian Komunikasi Universitas Indonesia. Profil pengguna internet Indonesia 2014. Jakarta: Asosiasi Penyedia Jasa Internet Indonesia; 2015.

13. Frima R, Irawan B, Dirgantoro B. Perancangan dan implementasi sistem informasi posyandu terintegrasi berbasis android. e-Proceeding Engineering. 2016;3(3):5013-21.

14. Munawaroh S. Model informasi monitoring kesehatan ibu dan bayi pada posyandu dalam rangka upaya peningkatan kesehatan keluarga. Dinamik. 2014;19(1):76-85.

15. Savitri N, Nurwasito H. Pengembangan aplikasi mobile untuk pelayanan administrasi posyandu dengan menggunakan Google Maps Api Geolocation Tagging. JPTIIK. 2018;2(1):63-72.

16. Castells M. The impact of the internet on society: a global perspective. In: Fox J, editor. Change: 19 key essays on how the internet is changing our lives. Catalonia, Spain: BBVA: 2013. p. 127-48.

17. Martini, Mufida E, Meitry J. Aplikasi parenting untuk makanan sehat bayi berbasis 
android. JITK. 2018;3(2):239-44.

18. Izah N, Bakhar M, Andari ID. Pengaruh penggunaan aplikasi stimulasi tumbuh kembang terhadap pengetahuan ibu dan pertumbuhan balita umur 9-24 bulan. JRMP. 2018;7(2):328-33.

19. World Health Organization (WHO). Early childhood development and disability: a discussion paper. Geneva, Switzerland: WHO Press; 2012.

20. Ulfah E, Rahayuningsih SE, Herman H, Susiarno H, Gurnida DA, Gamayani U, et al. Asuhan nutrisi dan stimulasi dengan status pertumbuhan dan perkembangan balita usia 12-36 bulan. GMHC. 2018;6(1):12-20.

21. Suryanto, Purwandari H, Mulyono WA. Dukungan keluarga dan sosial dalam pertumbuhan dan perkembangan personal sosial, bahasa dan motorik pada balita. Kemas. 2014;10(1):103-9.

22. Notoatmodjo S. Promosi kesehatan dan perilaku kesehatan. Jakarta: Rineka Cipta; 2012.

23. Ahmadi A. Psikologi umum. Revised Edition. Jakarta: Rineka Cipta; 2011.

24. Setiawan W. Sistem informasi posyandu dengan SMS gateway menggunakan metode ontology dalam menjawab pertanyaan. e-Proceeding Engineering. 2015;2(1):168895.

25. Snyder JS, Schwiedrzik CM, Vitela AD, Melloni L. How previous experience shapes perception in different sensory modalities. Front Hum Neurosci. 2015;9:594. 